\title{
COMPARATIVE ANALYSIS OF EFFICIENCY OF GEOPORTALS OF UKRAINE AND THE EUROPEAN UNION
}

\author{
E. Butenko, candidate of economic sciences, associate professor

\section{Lutskyi,magistrate}

National Network of Web-resources that provides public access to spatial information at this stage of existence, doesnot have single platform and structure, and is represented by a large number of unrelated websites.

The article explores in detail the Ukrainian geoportals that are in high demand both among land survey specialists and among ordinary users interested in obtaining spatial data, and compares them with relevant European services, analyzes their content, advantages and disadvantages of both comparable parties in accordance with what is proposed the variant of structuring national web resources and ways of their improvement based on European experience.

Keywords: geoportal, structure, spatial data, web resources.

Relevance of the problem:At the present stage of human development in the period of active globalization, Internet has become the most popular way to store all kinds of information and spatial as well. Now in all developed countries, citizens have free access to spatial data through the Internet, using geoportals.

As a term, the concept of geoportals - is a point of access to Internet or local network infrastructure, tools and spatial data processing by using web browsers. However, this includes a fairly extensive and well-developed structure as the data itself that retain these portals and methods of visualization and processing.

With development of Internet technologies, methods of obtaining spatial data that are publicly available greatly simplified, now, any interested in this person just open a browser and use geoportals service, but it follows a major problem - find relevant information in the vast World Wide Web. 
The term "cloud" storage is a prerequisite for rapid and easy access to the data concerned (authorized) users and organizations to the principles of transparency and impartiality. However, searching for specific data via such services require considerable efforts and skill, especially for people ignorant in this area. This is mostly due to the lack of a unified platform of Ukraine, and interconnected structure (architecture) placement location.

The aim of this articleAnalyze theavailable geoportals of Ukraine, offer them for structuring the basic content information and provide a comparative analysis of geoportals in the European Union.

\section{Analysis of recent researches and publications.}

Recent research in related areas are carried out by following scientists: Butenko E.V.,Dorosh A. J.,Dyshlyk O. P., Iwaniec J.J., Kharitonenko R. A., Sinitsin O.V., Stepanets V. V., Tarnopolsky A. V., Vasyuhin M. I.,

In their publications scientists Ivantsov J.J., Sinitsyn O.V. and Vasyuhin M.I.,discussed the concept and architecture of building geoportals as the main component of geoinformation system of precision agriculture. Revealed a number of shortcomings of existing geoportals. A software tool rendering heterogeneous data as discrete geographic area.

Innovative methods for collecting, storing and accessing information are considered byButenkoE.V. andKharitonenko R.A. in their work, they noted that currently the main method of getting information on the state of the earth's surface is aerial photogeodezic survey and remote sensing techniques, the results of which are currently mostly publicly available on geoportals monitoring land.

The writings Stepanets V.V. and Butenko E.V. The role of land monitoringin the conduct of agricultural land and improve agricultural. 
In the article "geospatial data infrastructure in Ukraine" scientists Dorosh A.J., Dyshlyk O.P., andTarnopolsky A.V. analyze problems of modern national geospatial data structure (NGDS) examine methodological errors in the formation of ideological principles and legal framework NGDS.

However, current trends geoportals functioning in Ukraine require further study structuring, establishing linkages between existing services and forming a common platform for the implementation of activities in the development of land relations and European integration processes in the country.

\section{Presenting of main material:}

Modern development of land relations, economic globalization and the beginning of the integration process to the international community needs a clear, credible public information. In the present structure of the information environment presents a number geoportals Ukraine, which is currently the most popular among users and provide access to information that often is used in solving various issues that require the use of land as geospatial base.

Currently, the operation of existing geoportals Ukraine gives users access to the following information:

- Information concerning the administrative and territorial division;

- cadastral information of all types and levels;

- data on the national geodesic network;

-land monitoring data;

- regulatory framework of land management actions and decisions.

In a meantime, information is available in this form can effectively solve the following problem:

- create and maintain spatial database objects; 
-promptly receive relevant information about the area (informing citizens);

-use spatial analysis;

- organize a system of electronic document;

- organize jobs web-tools;

-create conditions for transparent management.

After analyzing the available current national web resources they can offer the following structure:

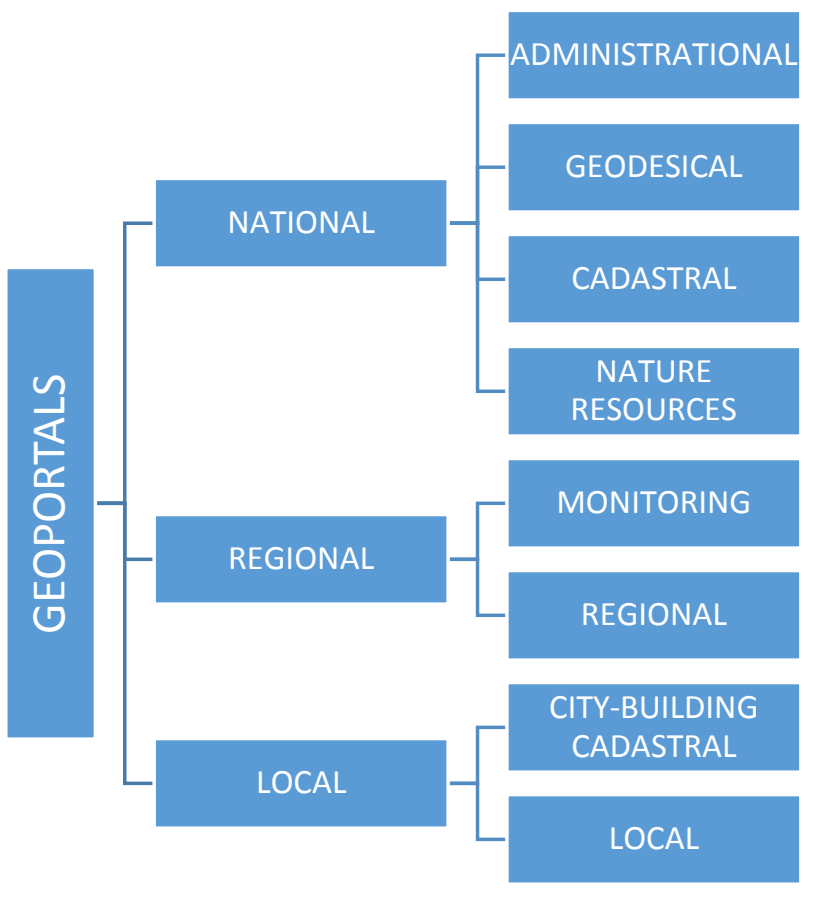

Consider more geoportals national level. These include "geoportal administrative and territorial structure of Ukraine", which proposed structure falls under the category of "administrative". Web address:http://atu.minregion.gov.ua.

Designed SE "Research Institute of Geodesy and Cartography" on behalf of the Minister of Regional Development, Construction and Housing and Communal Services of Ukraine Gennady Zubko. 
Is a database of metadata and administrative units, topography, roads and railways, legislative data on changes of administrative organization, plans forming area communities, data on merged community and others.

Portal structure consists of the following elements:

-Directory - in tabular form displays information about the unit Ata and united community

- map - visualizes the data directory, allowing visually acquainted with the geographic location of each unit Ata, or project a united community, learn their limits;

- community project - contains the Cabinet of Ministers "On approval of the long-term plan communities" and "long-term plan of forming the community areas" for all regions of Ukraine;

- united community - contains information about existing community united by regions separately.

-Parliament resolution - in tabular form leads all Parliament resolution regarding Ata sorted by date of adoption and reflection summary of the resolution, referring to the download file;

-The decision of the regional councils - duplicates the section "Resolution of Parliament" at the level of regional councils of Ukraine.

The purpose of this operation is to support geoportals to date database of Ata Ukraine and provide visitors information on adminstratyvno-territorial division and its regulatory framework.

Next, consider the portal "state geodetic network of Ukraine", according to the proposed structure to assign surveying. Web address:http://dgm.gki.com.ua.

It was developed at the Research Institute of Geodesy and Cartography. Is part of the national geospatial data infrastructure that is designed to support a variety of geospatial data interoperability through the use of a single coordinate bases Ukraine. 
Objective of the portal is:

-educate general state geodetic network of Ukraine;

- access to information about the state geodetic coordinate system referentsnu USC 2000 and passports regional local coordinate systems formed from the system of coordinates USC-2000,

- familiarization with the location of geodetic points in a particular area;

-obtain information about the technical characteristics of geodetic points;

-opportunity to sample items from the list for the purpose of placing the order for the exact coordinates in due course;

- perform coordinate conversion operations and transforming coordinates from various coordinate systems in others;

- provide user feedback for further information about the item, including the condition of the item, the way the entrance to it, its location photos and more.

Today the most usable geoportals in land management business among professionals and among ordinary Ukrainian who interested cadastral data division is a portal "Public cadastral map of Ukraine", which clearly referred to as "inventory." Web address:http://map.land.gov.ua

Represents a portal which published public inventory information. Site structure is simple and easy, provided one web page (see. picture 1) 


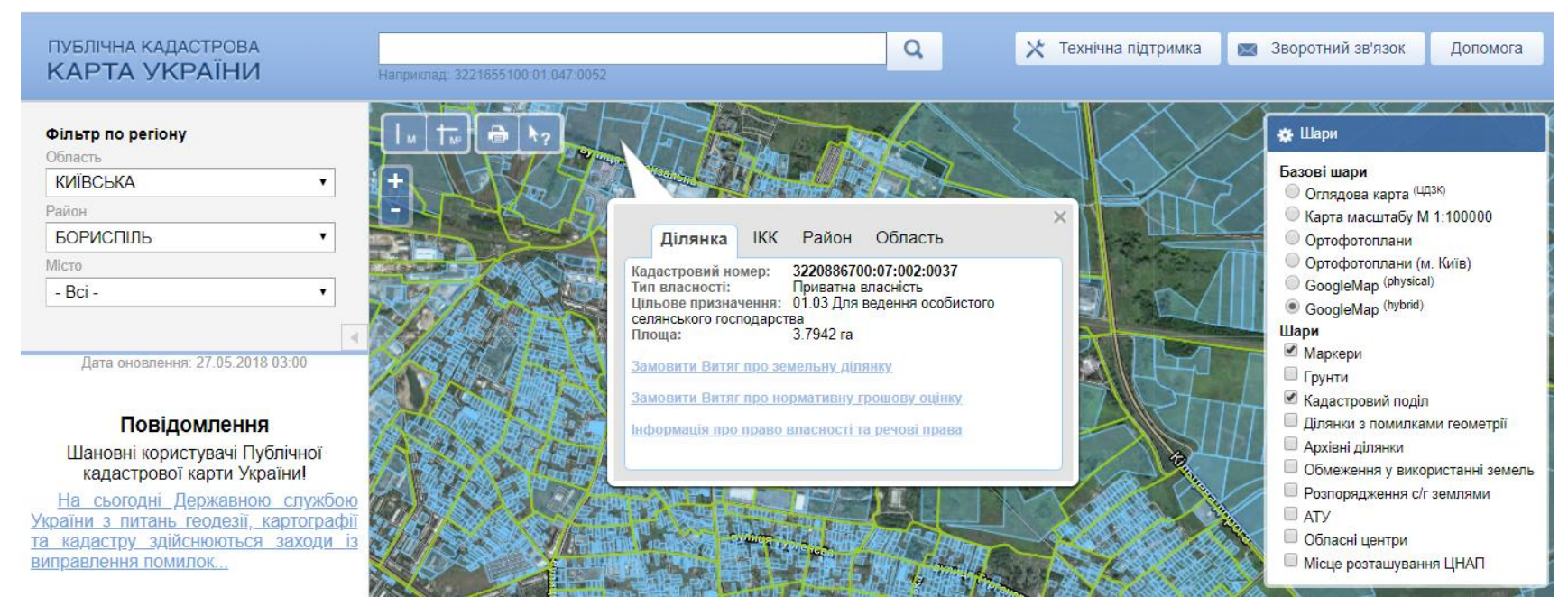

Picture 1. Structure of geoportal "Public cadastral map of Ukraine"

As shown in the figure at the top of the home page site is search string section for the cadastral number, with the following format input; the left side is occupied filters administrative-territorial units, right - layers which are optional, can be overlaid on the base card, which also has alternatives and elected to the list of "Base layer". The central part of the resource itself occupies card set, respectively, for the individual needs of the user.

In addition to visualizing spatial data portal also provides an opportunity to obtain information about any accrued in the land, provided identification that asks for this information. It's enough to find desired area on the map, select it, and dialog with basic inventory information to choose an item, and then identified a convenient way: via BankID, a mobile operator's digital signature or email.

Next in the proposed structure is a portal of natural resources, which include geoportals "Water Resources of Ukraine" and "Forest Fund of Ukraine," the relevant web addresses: http://map.davr.gov.ua and http://www.lisproekt.gov.ua

Currently these online resources are finalized and functioning only in beta, so a detailed view them - is pointless, since the final functionality is currently unknown, but it is worth noting that in the current version, the site forest Ukraine allows acquainted with the services provided by the "Ukrderzhlisproekt" and gives the orders 
necessary for their contact information. In turn, the portal of water resources is based on public cadastral map, with a similar interface and processing tools (see. picture 1), but instead of inventory data, displays detailed information on the national drainage.

By geoportals regional level of coverage in the proposed structure related web resources, reflecting the results of the monitoring of natural resources and geoportals areas.

Geoportals existing environmental monitoring based on remote sensing of the earth's surface, deserve special attention Website "geoportal RS" (web address: http://portal.dzz.gov.ua/) and "departmental geoportal" (web address: http://www.sich.org.ua/) That despite working in test mode provides access to a variety of spatial data obtained by remote sensing, and the results of their treatment, presented as example for all possible napryakamy from the level of rainfall and productivity of crops to the fire zones and the likelihood of melting snow.

Regional geoportals data mainly reflect inventories at urban areas example is "geoportal CBC Odesa region" web address http://gradportal.od.ua/But there are similar portals for all regions of Ukraine.

The final terms of the proposed structure is "local", which divides into two types: "urban cadastre" and "City." The first type is localized regional geoportals MBC on the city level, as data reflecting urban cadastre, but at the level of settlements. As an example, the portal "CBC Kyiv city" in the web addresshttp://mkk.kga.gov.ua/. In turn, "urban" geoportals provide more useful information for everyday use ordinary residents of settlements. For example, for the city of Kyiv created geoportal "Parking", which allows you to view information about available parking spaces in all areas of the capital, and gain analytical data, for example - the report on the number of parking spaces for specific addresses in the boroughs. 
As a result, we can say that the Ukrainian public Internet source geospatial data with sufficient information security, both specialists in the field of land resources and for ordinary users. Geoportals national network is a powerful tool that can solve a wide range of problems of land, and at the same time provide information used by millions of Ukrainians in everyday life. Among the identified shortcomings may be noted that a large number of portals rather is under, and the most popular among Ukrainians Website "Public cadastral map" has a significant number of errors geometry cadastral division, but the main drawback is that portals do not have a common platform causing serious difficulties in finding the necessary data. To address this shortcoming, You can use the European experience in providing online access to public spatial data. An example of this is the experience of spatial data infrastructure EU "INSPIRE", established in accordance with Directive 2007/2 / EC of the European Parliament and of the Council of 14 March 2007.

Web address: http://inspire-geoportal.ec.europa.eu/. Portal is a single structure of the European Union heprostorovyh data with user-friendly interface and a large number of web tools to process available data. Home page contains four links:

-Discovery / viewer;

-Validator;

- Metadata editor;

- Resource browser.

For users who are not experts in land resources, useful to first link "Discovery / viewer", if you go for it - a page shown in picture 2. 


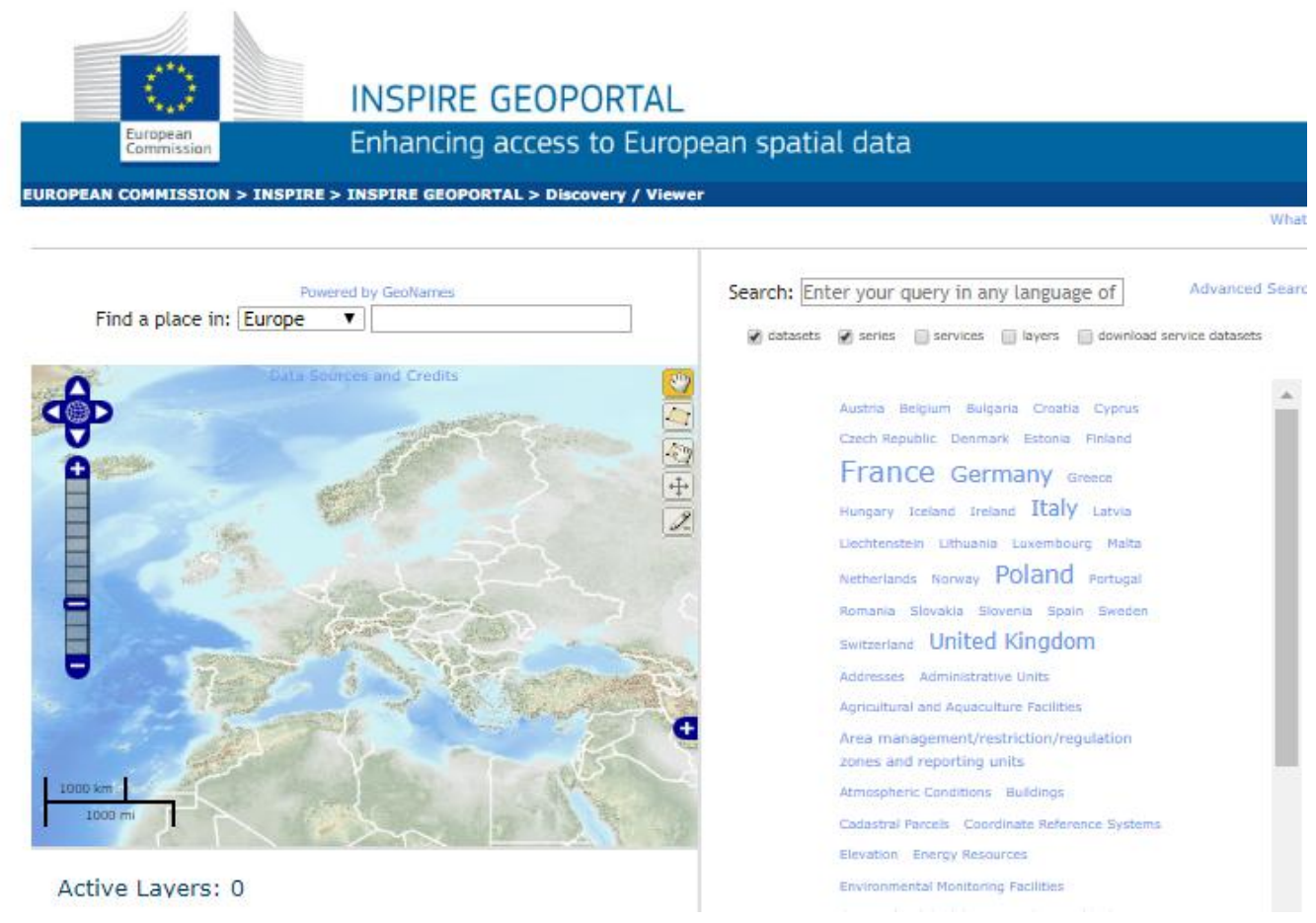

Picture 2 - Interface of Inspire geoportal

From the figure shows that web page is split in two: the right part is textual, descriptive information displayed according to the user's request, left the same part is visualization of the information on the card, which also contains the tools of processing, such as measurement of distances or given polygon area. In both parts of the page are the search terms which users can enter any query concerning spatial data instantly receive the search results and choose which ones to display on the map.

Thus, this geoportal denied basic problem of Ukrainian web resources - large number of individual portals because Inspire, in essence, cloud storage of consolidated spatial data of all the European Union.

Conclusion: national network geoportals at this stage of existence, allows users to receive and process a wide range of spatial data acquainted with the legal and regulatory basis of specific land management decisions ordering land surveying, legal or other services, public or private organizations online, use location data processed by special services in everyday life. However, further development of the national 
infrastructure of geospatial data, especially in the current context of globalization and integration into the European community, it is important to take into account the experience of the European Union, as the creation of a global, consolidated network of spatial data country provides free and easy access to public information on the principles of transparency and objectivity.

\section{References}

1. Forest Fund of Ukraine. Available at: http://www.lisproekt.gov.ua/pro-webulr

2. Geoportals of Ukraine. Available at: http://mapexpert.com.ua/index_en.php?id=196\&table=news

3. Geoportal of the administrative-territorial system of Ukraine. Available at: http://atu.minregion.gov.ua/ua/home

4. INSPIRE Directive. Available at: http://wikinsdi.dzk.gov.ua/wiki/Directive_INSPIRE

5. INSPIRE Geoportal. Available at: http://inspire-geoportal.ec.europa.eu/

6. Public cadastral map. Available at: http://map.land.gov.ua/kadastrova-karta

7. State geodetic network. Available at: http://dgm.gki.com.ua/

Бутенко С.В., Луцький В.С.

ПОРІВНЯЛЬНИЙ АНАЛІЗ ЕФЕКТИВНОСТІ ФУНКЦІОНУВАННЯ ГЕОПОРТАЛІВ УКРАЇНИ ТА ЄВРОПЕЙСЬКОГО СОЮЗУ

Національна мережа веб-ресурсів, що надають доступ до публічної просторової інформації, на даному етапі існування, не має єдиної платформи та структури, і представлена великою кількістю не пов'язаних між собою інтернет-сайтів.

В статті детально розглянуті українські геопортали, які користуються широким попитом, як серед фахівців землевпорядної справи, так і серед звичайних користувачів зацікавлених в отриманні просторових даних, проведено порівняння 3 відповідними європейськими сервісами, проаналізовано зміст, переваги та недоліки обох порівнюваних сторін, відповідно до чого запропоновано варіант структуризації національних веб-ресурсів та шляхи їх покращення спираючись на європейський досвід. 
Ключові слова:геопортал, структура, просторові дані, веб-ресурс.

БутенкоЕ.В.,Луцкий В.Е.

\section{СРАВНИТЕЛЬНЫЙ АНАЛИЗ ЭФФЕКТИВНОСТИ ФУНКЦИОНИРОВАНИЯ ГЕОПОРТАЛОВ УКРАИНЫ И ЕВРОПЕЙСКОГО СОЮЗА}

Национальная сеть веб-ресурсов, предоставляющих доступ к публичной пространственной информации, на данном этапе существования, не имеет единой платформы и структуры, и представлена большим количеством не связанных между собой интернетсайтов.

В статье подробно рассмотрены украинские геопорталы, которые пользуются широким спросом, как среди специалистов землеустроительного дела, так и среди обычных пользователей, заинтересованных в получении пространственных данных, и проведено сравнение с соответствующими европейскими сервисами, проанализировано содержание, преимущества и недостатки сравниваемых сторон, в соответствии с чем предложен вариант структуризации национальных веб-ресурсов и пути их улучшения опираясь на европейский опыт.

Ключевые слова: геопортал, структура, пространственные данные, веб-ресурс. 